\title{
A multidimensional Approach to Clinical Quality
}

(1) Tunçay Palteki

Biruni University Faculty of Health Sciences, İstanbul, Turkey

Submitted: 09.05.2019 Accepted: 24.05.2019

Correspondence: Tunçay Palteki, Biruni Üniversitesi Sağlık Bilimleri Fakültesi, İstanbul, Turkey

E-mail: tuncaypalteki@gmail.com

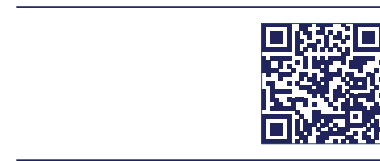

Keywords: Clinical quality; evidence-based medicine; medical error. This work is licensed under a Creative Commons
Attribution-NonCommercial 4.0 International License.

\begin{abstract}
Quality improvement studies have come to the forefront to eliminate the failure rates related to patient safety. The concept of quality in healthcare needs to be viewed from a broader perspective. The dimensions of healthcare quality have been tried to be expressed by many institutions and authors from different perspectives. A multidimensional approach to clinical quality aims to develop a more comprehensive perspective regarding the prevention of medical errors. Many factors, such as evidence-based practices, working environment, teamwork and the infrastructure of information technologies, are effective in the clinical quality process. Evidence-based medicine is a systematic approach for physicians to make decisions based on the best available evidence, combined with their own experience and patient characteristics and choices. The main purpose of evidence-based medical practices is to ensure that clinical decisions are made based on the best scientific evidence of the time. Starting with the formation of an appropriate question related to the problem, the process from the evaluation of the performance of the evidence-based practice consists of several steps. In this article, clinical quality is tried to be examined with all of its processes.
\end{abstract}

\section{INTRODUCTION}

We are witnessing the multi-faceted quality improvement efforts of clinicians, managers and policymakers to improve healthcare services in our age. However, we see that the most effective strategies associated with quality improvement come from the clinical field. On the other hand, the quality improvement strategies of managers and policymakers focus on accreditation studies along with the quality and efficiency evaluations of the institutions.

Many studies at the end of the last century and at the beginning of the new millennium have confirmed failures associated with medical errors. Some of these studies have demonstrated that $45 \%$ of the patients with acute or chronic diseases are deprived of evidence-based practices for the prevention of complications, and $20 \%$ of the patients are being harmed by undesirable effects related to erroneous medical practices and healthcare. They have also shown that $20-30 \%$ of tests, procedures and drugs administered to patients are unnecessary and contrary to evidence -based medicine. ${ }^{[1-3]}$ However, the first legal regulations for medical errors date back to the Hammurabi period in Mesopotamia (I792-I750 BC). 'First of all, don't give harm' (primum nil nocere) approach, which has also become a doctrine in the field of medicine, was expressed by Galenos, who lived in Anatolia between the years 130 and 210. Instructor Ernst Codman, MD, PhD from Harvard Medical School and Massachusetts General Hospital is regarded as the first pioneer to establish evidence-based medical practices remarkably. Codman stated that trying to understand why the treatment failed in some patients would contribute to the treatment of patients to be treated later. ${ }^{[4]}$ The determination of the importance and place of safety concerns that date back to remote past among the causes of death can only be realized nowadays. Adverse events in health care have been reported in many publications since the $1950 \mathrm{~s} .{ }^{[5-8]}$

To eliminate these failures related to patient safety, quality improvement studies have come to the forefront. The first signs of these studies at the institutional level were revealed in the United States. The American College of Surgeons was founded in 1913 to improve the quality of care for surgical patients, setting high standards for surgical training and practice. The first "standard" document for hospital standardization was adopted by the Board of American College of Surgeons on December 20, 1919. This document on standards consisted of five items on a single page. ${ }^{[9]}$ Then, in 195I, the first accreditation organization in the United States, "Joint Commission on Accreditation of Healthcare Organizations," was established. In the following years, quality and accreditation activities spread rapidly and many countries developed 
and implemented their own quality and accreditation processes.

In 1996, a three-stage evaluation was initiated by the Medical Institute to improve the quality of healthcare in the United States. In the first stage, the severity and prevalence of the quality problems in the healthcare services were revealed and it was determined that the center of the problems was excessive, wrong and inadequate use of these services. In the second phase, with the reports titled "Err is human: building a safer health system" and "Overcoming the quality gap: a new health system for the $2 \mathrm{I}^{\text {st }}$ century" and published between 1999 and $200 \mathrm{I}$ highlighted the necessity of radical changes. In the third stage, it was aimed to render functionality to the vision of the health system put forward to overcome the quality gap with the participation of all stakeholders and to focus on the reforms concerning the system's environment, health organizations, clinicians, and patients. ${ }^{[7,10]}$

As in the whole world, many studies have been carried out for similar problems related to patient safety and quality in our country, Turkey. In Turkey, quality studies have accelerated with the Health Transformation Program, and the first Health Quality Standards Hospital Kit was published in 2005 and by 2015, its 5th version was released. At the same time, as a result of the accreditation activities, the Accreditation Standards in Health Hospital Kit was prepared and as of 2018, accreditation audits started. Both Health Quality Standards and Health Accreditation Standards primarily target patient safety. ${ }^{[1,12]}$

The concept of quality in healthcare needs to be viewed from a broader perspective. The dimensions of health service quality have been tried to be expressed by many institutions and authors from different perspectives. In this article, the clinical quality will be evaluated from many perspectives. First of all, medical error and clinical quality approach will be emphasized and evidence-based medical practices will be discussed. Then, briefly, the relationship between work environment and clinical quality, the effects of teamwork on patient care quality and the effects of informatics on clinical quality will be evaluated.

\section{Medical error}

All kinds of activities ranging from simple diagnostic and treatment methods to the most complex surgical inter- ventions carried out by the individuals who are legally authorized to perform the medical profession according to the principles and rules generally accepted by medical science for the purposes of diagnosing and treating a somatic, physical, psychological illness, and deficiency, palliating the disease or relieving the pain of the disease or protecting people from discomfort, or for population planning purposes, can be defined as medical interventions. For the legality of medical interventions, four conditions must be met. Namely, the intervention should be carried out by authorized persons; it should be directed to the intended purposes, the patient's consent should be obtained and conformed to the generally accepted principles and rules of medical science. Medical errors may occur in the diagnosis and treatment stages, as well as due to lack of protective procedures, lack of follow-up, or erroneous transfusion and laboratory processes. ${ }^{[13]}$

Although modern medicine has made significant progress in the diagnosis and treatment of diseases today, it has also brought about complex and costly processes. The intensity of the technological infrastructure in the medical care process, the diversity in human resources and the rapidly expanding database face us as the main causes of complexity. A single failure within this complex structure may result in the failure of the whole process. Unsafe healthcare services and medical errors bring about adverse effects on patients, leading to various undesirable conditions, including loss of confidence in the healthcare system.

There are many levels in the healthcare delivery process that can identify factors that are harmful to the patients. As shown in Figure I, there is a broad spectrum from the institutional level to the patient level. ${ }^{[14]}$ The Francis Report, published as a result of a public survey conducted by the NHS Foundation in Mid Staffordshire in the UK, states that healthcare-related problems are often related to lack of leadership, ineffective communication, poor organization and teamwork, and the lack of an appropriate tool to assess quality of care. ${ }^{[15]}$

\section{Clinical quality approaches to medical errors}

The reality of medical error has triggered efforts to take relevant precautions. The factors causing the medical error are directly related to the factors affecting the clinical practice. Because of the broad spectrum of these factors,
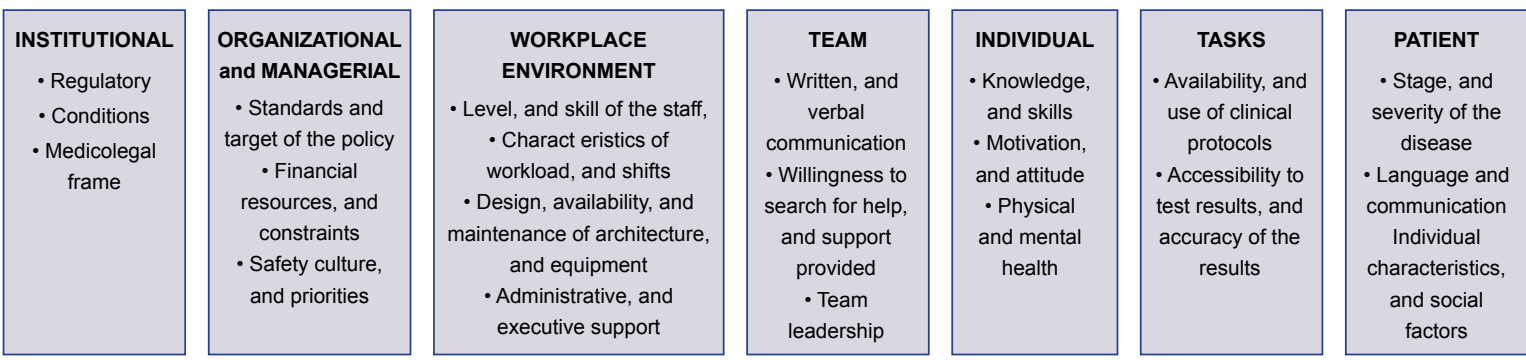

Figure 1. Factors affecting clinical practice (Source: Vincent, 2003). 
the solution to be developed for medical errors reveals that they should be within this scope. In fact, quality studies, which have a history of nearly a century, began at a time when it was not revealed that the medical error was of such magnitude. While progress in quality studies was initially narrow scoped, nowadays, it covers all processes, including the clinical dimension.

The objectives of the quality approach in healthcare are listed similarly by scientists and institutions. These include concepts, such as efficiency, effectiveness, productivity, accessibility, safety, equity, compliance, timeliness, acceptability, patient-focused, satisfaction, continuity, legality. Of these concepts, efficiency, effectiveness, safety, compliance, timeliness and continuity are related directly to clinical quality, while others are related to quality improvement dimension.

Although studies on clinical quality are expressed in different concepts across countries, the goals are the same. For example, the concept that is designed to promote and ensure good practice in the UK ${ }^{[16]}$ and defined as "clinical governance" in the literature aims to guide and control clinical practices through structures, systems and standards to create a culture. Clinical governance aims to put clinical quality at the center of healthcare delivery and targets at the implementation of evidence-based medical practices with qualified human resources, appropriate facilities and equipment. Besides, clinical governance also includes continuous quality improvement. Clinical governance aims to improve the practice of health professionals, guarantees that risks are managed and attaches importance to learning from incidents and accidents (Fig. 2). ${ }^{[17]}$

\section{Why are evidence-based medical practices necessary?}

Evidence-based practice is defined by Long and Harrison as the process of systematically finding and using contemporary research results that are essential to clinical decision-making. As Belsey and Snell put it, evidence-based medicine is part of a multifaceted process in achieving clinical efficacy. They defined the main elements of this process as follows: ${ }^{[18]}$

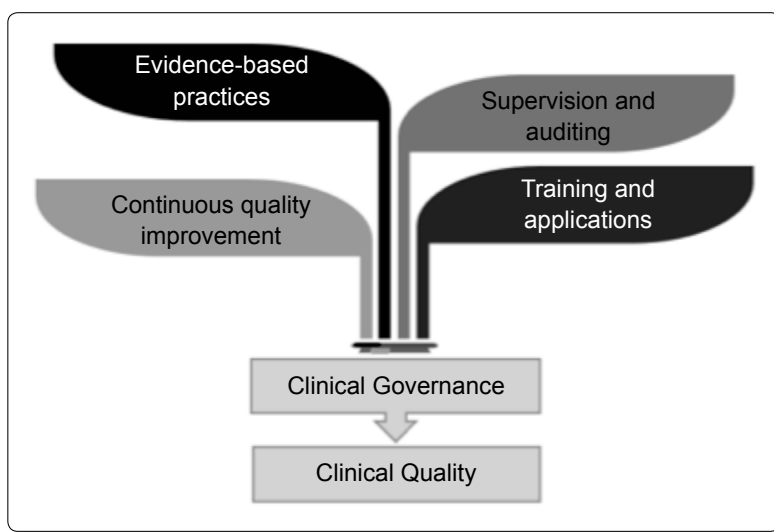

Figure 2. The relationship between clinical governance and clinical quality.
- Produce evidence through research and scientific review

- Creation and dissemination of evidence-based clinical guidelines

- Evidence-based and cost-effective implementation through the change in training and management

- Appropriate assessment of application and patient outcomes through this process, including clinical supervision.

Evidence-based medicine (EBM) is a systematic approach for physicians to make decisions by combining their experiences and patient characteristics and choices in the light of the best available evidence. ${ }^{[19]}$ Today, individual decision-making approach based on clinical experience has been replaced by evidence-based decision-making because of differences and inconsistencies between clinical applications, difficulties in the pursuing the increasing medical literature as a result of the rapid increase in the number of studies in the field of health, and at the same time, due to discrepancies exist between practice and research. ${ }^{20]}$ Without a doubt, evidence-based practices play an important role on the road to clinical quality.

Evidence-based medical practice essentially encompasses a critical approach together with problem-specific literature review. On the other hand, in the approach based on clinical experience and opinion, subject-specific textbooks and literature research come to the forefront and decisions are made based on individual intuition. Thus, physicians need to develop some knowledge and skills to reach useful evidence, to evaluate and to incorporate them into practice. Secondary publications, such as clinical practice guidelines and meta-analyses, have been developed to address physicians' needs for easier access to new and valid information. ${ }^{[21]}$

Clinical practice is about making choices. Which test would be better to learn more about a certain condition? What is the most effective treatment for this patient? The answers to these questions depend on the practitioner's knowledge, skills and attitudes, available resources and patient concerns, expectations and values. In the early 1990s, David Sackett and his colleagues first used the term 'evidence-based medicine', which means 'integrating individual clinical experience with the best clinical evidence available from systematic research'. They then developed their definition to take patient values into account. Evidence-based medical practice is about trying to improve the quality of information on which health decisions are based. Evidence-based medical practice helps practitioners avoid overloading information, but it also helps them to find and apply the most useful information. The main elements of the evidence-based approach to practice include recognizing uncertainties about clinical information, using research information to reduce uncertainties, distinguishing between strong and weak evidence, and measuring and communicating uncertainties with their probabilities. In 1972, British epidemiologist Archie Cochrane criticized healthcare at that time in his book "Effectiveness and Ef- 
ficiency" and stated that most of the treatment decisions were not based on a systematic examination but rather based on wide and variable literature, expert opinions, and the worst, it was based on the information derived from trial and error. In the early 1990s, Cochrane's ideas for systematic review began to institutionalize and internationalized. ${ }^{[22]}$

Physicians have access to the information they need about clinical practice in two ways. The first of these is our expertise about problems that may arise just in case or the general information about issues that we are interested in or have felt a shortage. The other is the information we want to reach when we need it for a particular problem. This information will sometimes be needed when we decide to make a choice between two different treatment methods or diagnostic tests.

The main purpose of evidence-based medical practice is to ensure that clinical decisions are made with the best scientific evidence of the time. Sackett et al. ${ }^{[23]}$ indicated that the implementation process of the evidence-based medicine consists of five steps as follows:

I. Formulating an appropriate question related to the information or problem needed

2. Searching for the best available evidence (especially secondary sources)

3. Critical evaluation of the available evidence

4. Implementation of the results through integrating results with clinical experience and patient values

5. Process monitoring and performance evaluation of evidence-based practice.

\section{Formulating an appropriate question specific to the problem}

The question will change concerning the problem. The most common type of clinical question we see in practice relates to how to treat a disease or condition or how to alleviate other health problems. Besides, there may also be questions regarding the etiology or risk factors, diagnosis, prognosis, and prevalence of the problem in the population. In addition, since the questions can be partially formulated, to find relevant answers to the problem in the literature become more difficult. Therefore, it is possible to provide an easy understanding of the answers by separating the questions into the components. For this, the PICO (T) approach is used. 'P' refers to the patient or problem, 'l' to the intervention, test, or exposure, ' $C$ ' to the comparison, ' $O$ ' to the outcome, and ' $T$ ' to the Timeframe.

Let us give an example of formulating the problem with the PICO approach. ${ }^{[22]}$ A 33-year-old mother who gave birth to a child with Down syndrome after her first pregnancy states that the diagnosis of this child can be made at the $18^{\text {th }}$ week of pregnancy. Your 35 -year-old patient, who is pregnant with her second child at her first gestational month, asks you whether or not there is any way to detect the presence of a similar risk earlier? In related hospitals, serum biochemistry and nuchal translucency ultrasound are used as the first-trimester test. On the other hand, you wonder if these tests are as reliable as conventional amniocentesis to guide the mother correctly. The components of PICO can be separated as follows:

- P-Patient-pregnant woman (first trimester)

- I-Index test-serum biochemistry and nuchal translucency ultrasound screening tests

\section{- C-Comparison-conventional amniocentesis}

- O-Outcome-definitive diagnosis (measurement technique sensitive and specific for Down syndrome)

In the light of this analysis, the question can be formulated as follows: Are nuchal translucency ultrasound scanning and first-trimester serum biochemistry test can yield accurate results as conventional amniocentesis for the diagnosis of Down syndrome in pregnant women or whether alternative tests have equivalent or better sensitivity and specificity when compared with conventional amniocentesis?

\section{Searching for the best available evidence}

Once an appropriate question has been formulated, the process of obtaining the best available evidence is initiated. Sources are searched from Pubmed and similar databases by priorly creating keywords. The " $4 \mathrm{~S}$ model" described by Haynes can be used to reach evidence. In the $4 \mathrm{~S}$ method, the lowest level is the "Studies" level, which includes primary studies, such as Randomized Controlled and Cohort studies. Immediately above is the level of "Syntheses" with systemic reviews. An example of this "4S method" is the "Cochrane Library loan, which helps to make decisions in healthcare based on information. Then comes the level of "Synopses", which contains evidence-based abstracts of primary and secondary research studies. At the top level, "Systems" is found. Although this level is not yet well developed, there are several related initiatives. ${ }^{[24]}$ The types of studies that provide the best evidence are different concerning question types. However, the best evidence comes from studies that are most likely to eliminate bias. The pyramid, called the evidence pyramid, listed the studies concerning the value of evidence (Fig. 3).

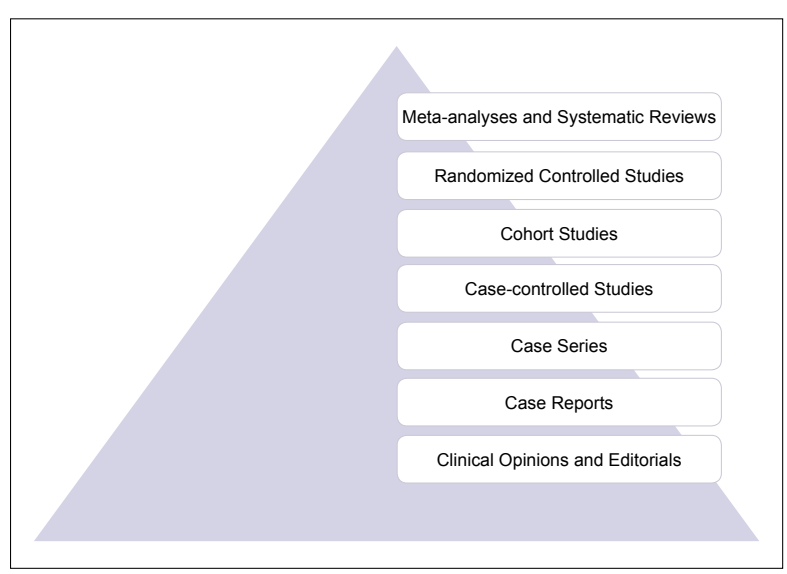

Figure 3. Evidence pyramid. 
Different research methods are being used to determine the level of evidence according to the type of problem associated with the issue. There are two study designs, mainly experimental and observational studies. Experimental studies are designed to minimize the risk of bias, i.e., to produce systematically indistinguishable results. The best evidence for cause-effect relationship can be obtained with high-quality experimental studies designed involving a large number of patients, randomized comparison groups, blind studies encompassing patients, practitioners, and data analysts, and lower number of patients lost to follow-up during the study was low. In this context, Randomized Controlled Trials are the best research model for determining evidence for intervention. Cohort studies investigating survival and etiology, and diagnostic and screening cross-sectional studies are observational studies. Systematic reviews of both experimental and observational studies increase the level of evidence. ${ }^{[25]}$

\section{Critical evaluation of the evidence obtained}

Medical practices are guided by knowledge, experience, experimentation and value systems. These components have a variable base of evidence to consider before deciding on care for patients. Randomized Controlled Trials often provide stronger evidence than observational studies. In the process of quality evaluation of the information obtained, analysis of the study design, critical evaluation, and grading of the level and quality of evidence are important. In the final stage to reach a decision on medical intervention, it is necessary to analyze the balance between benefit and harm of the application, to evaluate the strength of the proposal and to realize the implementation steps.

The hierarchy of evidence in scientific research and the characteristics of the research design are shown in Table I. ${ }^{25]}$

On the other hand, we can carry out the evaluation of scientific evidence based on a few simple questions. While the question word "Why? sets out the purpose of this research, the question "What kind of study?" describes the design and implementation of the study. On the other hand, "How good?" reveals its quality, "How big?" its ef-

Table I. The hierarchy of evidence in scientific research

\begin{tabular}{lccc}
\hline Type of research & \multicolumn{3}{c}{ Research design } \\
\cline { 2 - 4 } & Randomization & Prospective & $\begin{array}{c}\text { Control/ } \\
\text { Comparison } \\
\text { Group }\end{array}$ \\
\hline Randomized & + & + & + \\
controlled & - & + & + \\
Non-randomized & - & $+/-$ & + \\
Cohort & - & $-1+$ & + \\
Case-control & - & - & + \\
Cross-sectional & - & $-1+$ & - \\
Case series & - & - & - \\
Case reports & - & & \\
\hline
\end{tabular}

fect, "How reliable?" its reliability and "What happened?" its suitability and significance. The purpose of the clinical assessment tools is to perform an analytical assessment of the quality of the study to minimize bias. In this way, it helps us to decide whether the information/evidence is applicable or not. ${ }^{[25]}$

\section{Implementation of the results by integrating them with clinical experience and patient values}

The physician should look for answers to some questions during the decision-making process to determine whether the findings obtained in the previous steps are appropriate for the patient. These questions can be listed as follows: ${ }^{[22,25]}$

- Are the results appropriate for my patient and consistent with his/her expectations and values?

- Would my patient be eligible for the inclusion criteria of the study if his/her participation is requested?

- Does the study cover all clinically important aspects?

- Do treatment benefits outweigh potential risks?

With this evaluation, the physician combines the patients' individual characteristics, preferences, concerns and expectations with his/her experiences and uses them in the treatment of the patient. On the other hand, clinical guidelines, algorithms and protocols contribute to the physician's decision-making process.

The results and medical information should be made understandable to the patient and help the patient to make a decision. During the transmission of the evidence to the patient, the physician must pay attention to certain issues. We can list them as follows: ${ }^{[25]}$

- Understanding the patient's experience and expectations

- Partnership with the patient during clinical decision and treatment

- Providing evidence that will contribute to the understanding of uncertainties

- Considering patient values

- Focusing on the agreement

Thus, patients and their families can make an informed decision based on available evidence and patient values.

\section{Monitoring the process and evaluating the per- formance of evidence-based practice}

The final stage is about evaluating the performance of decisions and practices taken in the previous four stages. Thus, there will be an opportunity to intervene against unforeseen problems that may arise. On the other hand, application performance results will shed light on the physician's subsequent similar applications.

\section{Relationship between work environment and clinical quality}

A wide range of factors, from architectural structure to the design of the equipment used, from communication between employees to the noise, affect the quality of clin- 
ical care. Such elements constitute hidden conditions that cause errors to occur in the work environment. Eliminating the causes of such errors will have a positive impact on the quality of clinical care. The Reason stated that the work environment should be designed in a "human defectproof way".[26]

Carayon et al. ${ }^{[27]}$ (2006) indicated that interactions between individuals and work environment are effective on performance, safety, quality of work-life, employee health, the quality of goods produced and services provided. It is possible to see signs of human-environment interaction at each level of the structure-process-outcome sub-parts within Donabedian's system approach. ${ }^{[28]}$ For example, human resources, organization, technology and facility can be evaluated within the concept of structure, patient care in the process and patient safety and quality of health in the outcome.

Focusing on quality and patient safety in the design of the working environment has demonstrated that it will improve patient care. In the studies on the relationship between nurse and work environment, it was concluded that the work environment would affect the results of the quality of nursing care and patient safety. ${ }^{[29,30]}$

\section{The effects of being team on quality of patient healthcare}

Today's healthcare services require more interdisciplinary communication and cooperation than before. Effective communication between healthcare professionals is crucial to ensure that patients receive safe and high-quality care. It is expected that information sharing among health professionals is sufficient for safe and effective patient care. The most important element of being a team is the successful communication between the team members.
In the study conducted by Weller et al., ${ }^{[31]}$ covering many sectors and examining the factors related to team performance, it was defined that the teams should have five basic characteristics as follows:

I. Team leadership indicates coordination and planning, as well as contributing to the development of the team and providing motivation and a positive atmosphere.

2. Reciprocal performance monitoring: The creation of an appropriate environment to allow the identification of errors or overload of other team members.

3. Backup behavior: Required to provide supportive activities.

4. Ability to adapt: A team's ability to respond to changes in the environment and plan.

5. Team orientation: The belief that team goals, which are in line with the best for the patient, are more important than individual goals, taking into account the ideas and perspectives of others.

To reach these five dimensions of effective teams, members of the team must respect and trust each other to provide feedback on their performance and have good communication skills to communicate accurate information.

The Joint International Commission $(\mathrm{JCl})$, which provides accreditation services for health institutions, has indicated that $65 \%$ of unwanted incidents emerged due to poor communication. Communication between health professionals and between health professionals and patients plays a key role in ensuring and maintaining patient safety. Barriers to interpersonal communication may adversely affect patient care and cause medical errors.

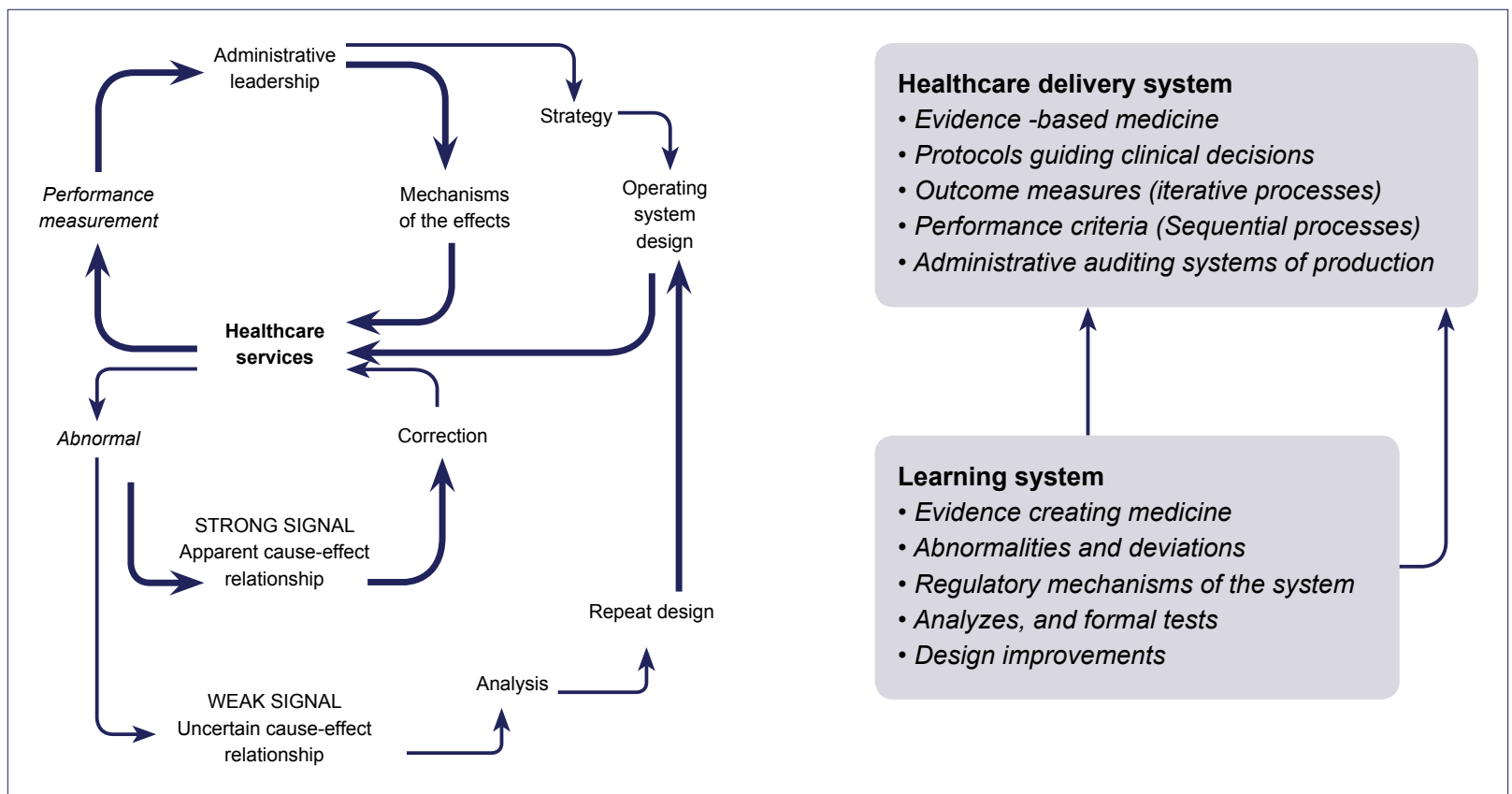

Figure 4. High-performance healthcare delivery in which performance and innovation are integrated (Source: Adapted by Karakaş and Birinci from "Bohmer, 2009"). 
Errors in communication may occur due to incorrect information exchange, unintentional alteration or loss of existing information, lack of timely access to information and inability to ensure information security. ${ }^{[32]}$ There is also evidence concerning possible improvement in clinical governance using specific techniques to improve information sharing, such as clearly reporting emergency situations, sharing crisis-related information or observations or decisions with the team by thinking out loud. ${ }^{[33,34]}$

Effective communication between team members reduces unwanted events, increases job and patient satisfaction, and has benefits concerning improving patient outcomes. ${ }^{[32]}$

\section{Informatics and clinical quality}

Effective reporting with a good flow of information is of particular importance in clinical quality. To ensure patient care, timely and accurate information of good quality should be obtained. In this way, it will be possible to determine the suitability of healthcare to accepted standards and healthcare performance with the standards. ${ }^{[18]}$ There is a need for an accurate structuring of electronic patient records in this regard. In recent years, the e-Pulse application is an important step towards achieving this goal.

E-pulse allows patients to manage their own health data and share it with healthcare providers. Thus, a strong communication network is established between the patient and the physician and enables the patients to participate in decisions and processes about their own health. Additional opportunities offered by the system include the freedom to receive services from the desired hospital without interruption of information; the elimination of repeated examinations, in particular, minimizing radiation exposure and shortening the duration of diagnosis and treatment, the possibility of reaching the right diagnosis earlier through information sharing and consultation, security of personal data and data-based early warning mechanisms. ${ }^{[35]}$

Efficient, effective and accurate data is the most important helper of physicians in providing personalized health services. It is especially important in providing a deeper insight into what will be better for a particular patient and in a better understanding of risks. Greater numbers of data, connectivity, information transformation and advanced analytics are also critical in preventing the serious risks involved in healthcare delivery. These risks range from complex diagnoses to the simplest procedures. Nowadays, a significant difference in the majority of high-performance healthcare providers strikes our attention. These institutions integrate performance and innovation by adding learning cycles to operational service delivery cycles (Fig. 4). ${ }^{[35]}$

Peer-review

Internally peer-reviewed.

Conflict of Interest

None declared.

\section{REFERENCES}

1. Asch SM, Kerr EA, Keesey J, Adams JL, Setodji CM, Malik S, et al. Who is at greatest risk for receiving poor-quality health care? $N$ Engl J Med 2006;354:1147-56. [CrossRef]

2. Brownlee S. Overtreated: Why Too Much Medicine is MakingUs Sicker and Poorer. Newyork: Bloomsbury; 2007.

3. Brown P, McArthur C, Newby L, Lay-Yee R, Davis P, Briant R. Cost of medical injury in New Zealand: a retrospective cohort study. J Health Serv Res Policy 2002;7:S29-34. [CrossRef]

4. Sur H. Hasta Güvenliği ve İlişkili Kavramların Ortaya Çıkışı. In: Sur H, Palteki T, Yazıcı G. Hasta Güvenliği. Ankara: Palme Yayınevi; 2019. p. 1-6.

5. Brennan TA, Leape LL, Laird NM, Hebert L, Localio AR, Lawthers AG, et al. Incidence of adverse events and negligence in hospitalized patients. Results of the Harvard Medical Practice Study I. N Engl J Med 1991;324:370-6. [CrossRef]

6. Wilson RM, Runciman WB, Gibberd RW, Harrison BT, Newby L, Hamilton JD. The Quality in Australian Health Care Study. Med J Aust 1995;163:458-71. [CrossRef]

7. Kohn LT, Corrigan JM, Donaldson MS. To err is human: Building a safer health system. Washington DC: National Academies Press; 2000.

8. Vincent C, Neale G, Woloshynowych M. Adverse events in British hospitals: preliminary retrospective record review. BMJ 2001;322:517-9. [CrossRef]

9. American College of Surgeons. The 1919 "Minimum Standard" document. Available at: https://www.facs.org/aboutacs/archives/ pasthighlights/minimumhighlight. Accessed Jul 03, 2019.

10. Institute of Medicine Committee on Quality of Health Care in America. Crossing the quality chasm: A new health system for the 21st century. Washington DC: National Academies Press; 2001.

11. TC Sağlık Bakanlığı Sağlıkta Kalite ve Akreditasyon Daire Başkanlığı. Sağlıkta Kalite Standartları Hastane. Ankara: TC Sağlık Bakanlı̆̆1; 2015.

12. TC Sağlık Bakanlığı Sağlıkta Kalite ve Akreditasyon Daire Başkanlığı. Sağlıkta Akreditasyon Standartları- Hastane Seti. Ankara: TC Sağlık Bakanlı̆̆ı; 2017.

13. Tapan B. Tibbi Hata ve Komplikasyon. In: Sur H, Palteki T, Yazıcı G. Hasta güvenliği.Ankara: Palme Yayınevi; 2019. p. 117-28.

14. Vincent C. Understanding and Responding to Adverse Events. N Eng J Med 2003;348:1051-6. [CrossRef]

15. Report of the Mid Staffordshire NHS Foundation Trust public. Francis Report. London: HMSO; 2013.

16. Onion CW. Principles to govern clinical governance. J Eval Clin Pract 2000;6:405-12. [CrossRef]

17. Gottwald M, Lansdown G. Clinical Governance - Improving the quality of healthcare for patients and service users. New York: Open University Press; 2014.

18. Sale D. Understanding Clinical Governance and Quality AssuranceMaking It Happen. New York: Macmillan Education; 2005.

19. Sackett D, Straus SE, Richardson WS, Rosenberg W, Haynes R. Evidence-Based Medicin: how to practice and teach EBM. 2nd ed. Edinburgh: Churchill Livingstone; 2000.

20. Evidence-Based Medicine Working Group. Evidence-Based medicine. A new approach to teaching the practice of medicine. JAMA 1992;268:2420-5. [CrossRef]

21. Yılmaz E, Çöl M. Kanıta Dayalı Tip. Journal of Clinical and Analytical Medicine 2014;5:537-42.

22. Glasziou P, Del Mar C, Salisbursy J. Evidence-based Practice Workbook. 2nd ed. Canberra, Australia: Blackwell Publishing; 2007.

23. Sackett D. Evidence-Based Medicine. Semin Perinatol 1997;21:3-5.

24. Haynes RB. Of studies, syntheses, synopses and systems: the 
' $4 \mathrm{~S}$ ' evolution of services for finding best evidence. ACP J Club 2001;134:A11-3. [CrossRef]

25. Nordenstrom J. Evidence-Based Medicine: In Sherlock Holmes' Footsteps. Stockholm: Blackwell Publishing; 2007. [CrossRef]

26. Bogner MS. Human Error in Medicine. $\mathrm{Nj}$ Hove UK: Lawrence Erlbaum Associates; 1994.

27. Carayon P, Schoofs Hundt A, Karsh BT, Gurses AP, Alvarado CJ, Smith M, et al. Work system design for patient safety: the SEIPS model. Qual Saf Health Care 2006;15:150-8. [CrossRef]

28. Donabedian A. An Introduction to Quality Assurance in Health Care. New York: Oxford University Press; 2003.

29. Sherman R, Pross E. Growing future nurse leaders to build and sustain healthy work environments at the unit level. The Online Journal of Issues in Nursing 2010;15.

30. Stimpfel AW, Djukic M, Brewer CS, Kovner CT. Common predictors of nurse-reported quality of care and patient safety. Health Care Manage Rev 2019;44:57-66. [CrossRef]
31. Weller J, Boyd M, Cumin D. Teams, tribes and patient safety: overcoming barriers to effective teamwork in healthcare. Postgrad Med J 2014;90:149-54. [CrossRef]

32. Velji K, Baker GR, Fancott C, Andreoli A, Boaro N, Tardif G, et al. Effectiveness of an Adapted SBAR Communication Tool for a Rehabilitation Setting. Healthc Q 2008;11:72-9. [CrossRef]

33. Tschan F, Semner N, Gurtner A, Bizzari L, Spychiger M, Breuer M, et al. Explicit reasoning, confirmation bias, and illusory transactice memory: a simulation study of group medical decision making. Small Group Res 2009;40:271-300. [CrossRef]

34. Siassakos D, Bristowe K, Draycott TJ, Angouri J, Hambly H, Winter $\mathrm{C}$, et al. Clinical efficiency in a simulated emergency and relationship to team behaviours: a multisite cross-sectional study. BJOG 2011;118:596-607. [CrossRef]

35. Karakaş H, Birinci Ş. Hasta Odaklı Sağlık Hizmeti Sunumunda ve Hataları Azaltmada Bilgi Teknolojilerinin Kullanımı. In: Sur H, Palteki T, Yazıc1 G. Hasta Güvenliği. Ankara: Palme Yayınevi; 2019. p. 431-54.

\section{Klinik Kaliteye Çok Boyutlu Yaklaşım}

Hasta güvenliği ile ilişkili bu başarısızlıkların ortadan kaldırılmasına yönelik olarak geçmişten günümüze kalite iyileştirme çalışmaları ön plana çıkmıştır. Sağlık hizmetlerinde kalite kavramına geniş bir perspektiften bakmak gerekmektedir. Sağıı hizmet kalitesinin boyutları birçok kurum ve yazar tarafından farklı bakış açıları ile ifade edilmeye çalışılmışır. Çok boyutlu klinik kalite yaklaşımı ile tıbbi hataların önlenmesine yönelik daha kapsamlı bir bakış açısı geliştirilmeye çalışılmaktadır. Klinik kalite sürecinde; kanıta dayalı uygulamalar, çalışma ortamı, ekip çaış̧ması, bilişim alt yapısı gibi birçok unsur etkilidir. Kanıta dayalı tıp, hekimlerin kararlarını, mevcut en iyi kanıtın ışı̆̆ında, kendi deneyimleri ve hastanın özellikleri ve seçimleriyle birleştirerek vermesi için belirlenen sistematik bir yaklaşımdır. Kanıta dayalı tıp uygulamalarının temel amacı, klinik kararların zamanın en iyi bilimsel kanıtları ile alınmasını sağlamaktır. Problemle ilişkili uygun bir soru oluşturulması ile başlayarak kanıta dayalı uygulamanın performansının değerlendirilmesine kadar giden süreç çeşitli basamaklardan oluşmaktadır. Bu makalede klinik kalite tüm süreçleri ile irdelenmeye çalışılmıştır.

Anahtar Sözcükler: Kanıta dayalı tıp; klinik kalite; tıbbi hata. 